\title{
Experimental Study of Correlation of Mechanical Properties of Al-Si Casts Produced by Pressure Die Casting with Si/Fe/Mn Content and Their Mutual Mass Relations
}

\author{
Marcel Fedak, Miroslav Rimar, Ivan Corny, and Stefan Kuna \\ Faculty of Manufacturing Technologies with Seat in Prešov, Department of Process Technology, \\ Sturova 31, 08001 Prešov, Slovakia \\ Correspondence should be addressed to Marcel Fedak; marcel.fedak@tuke.sk
}

Received 12 June 2013; Revised 11 October 2013; Accepted 11 October 2013

Academic Editor: Jainagesh Sekhar

Copyright ( 2013 Marcel Fedak et al. This is an open access article distributed under the Creative Commons Attribution License, which permits unrestricted use, distribution, and reproduction in any medium, provided the original work is properly cited.

\begin{abstract}
The submitted contribution addresses problems concerning influence of alloying elements $(\mathrm{Si} / \mathrm{Fe} / \mathrm{Mn})$ of $\mathrm{Al}-\mathrm{Si}$ pressure die casts (HPDC) on values of residual deformation. On the basis of results of executed experiments, mutual correlations are analyzed and described, while not only measurements results are evaluated but also metallographic outputs of obtained compounds from the view of their formation, occurrence, and size. The development of intermetallic phases structures $\mathrm{Al}(\mathrm{FeMn}) \mathrm{Si}$ as well as intermetallic ferritic phase $\mathrm{Al}_{3} \mathrm{FeSi}$ was observed. More verification experiments follow in order to apply obtained knowledge for improvement and/or preservation of casts properties on required level.
\end{abstract}

\section{Introduction}

Parts manufactured by pressure die casting distinguish by suitable properties in relation to their mass. In present, these products/casts are utilized in various spheres of industries, significant share of which is automotive industry [1]. An important requirement in this sphere is resultant mass of products, whilst all claimed properties are preserved. The trend of mass reduction leads to application of aluminiumbased materials, while demands on strength, extensibility, and other mechanical properties are on the same level as for Fe-based materials.

The paper describes basic impacts of chosen alloying elements on permanent deformation as a significant mechanical property. Mutual correlations between chosen alloying metals and resulting deformation measured on a group of casts are described. Consecutively these relations are observed during variation of content of the alloying elements in order to increase resulting strength of the cast. Providing stability in casting process is of great importance, since it has direct impact on resulting cast properties [2-4]. Aluminium alloys are die cast under pressure on casting machines with cold chamber $[5,6]$. Significant factor of the process is corrosive effect of liquid aluminium alloys particularly at higher temperatures, this effect makes it impossible to employ casting machines with hot chamber [6-8]. Horizontal cold chambers are relatively simple, and it is possible to apply higher specific pressure on the cast metal. Thus, it is possible to cast light-walled casts with smooth surface and high mechanical properties. These advantages of horizontal chamber make it possible to design large casting machines with voluminous loading chamber and closing force $F_{u}$ up to $30 \mathrm{MN}$, with gross cast mass $30 \mathrm{~kg}$ or more, in casting of aluminium alloys (charge utilization of $80 \%$ ) $[6,9,10]$.

The quality of aluminium casts produced by pressure die casting depends closely on the content of alloying elements $[5,6,11-15]$. The properties of chosen alloying elements are described in Table 1.

Concentration of alloying elements in the cast is chosen according to requirements on the cast properties; however, the concentrations are limited by recommended ranges [11].

Iron and silicium are very often contained in aluminium alloys. Both of these elements influence mechanical properties of the casts. Theoretical knowledge shows that iron 
TABLE 1: Characteristic, properties, and impact of chosen alloying elements [11, 12, 14-20].

\begin{tabular}{|c|c|}
\hline Element & Characteristic \\
\hline B & $\begin{array}{l}\text { Content refines structure and increases electrical conductivity in technically clean aluminium due to } \\
\text { precipitation of } \mathrm{V}, \mathrm{Cr}, \mathrm{Mo} \text {, and Ti from solid solution }\end{array}$ \\
\hline $\mathrm{Bi}$ & Alloying with this element improves mechanical machinability \\
\hline $\mathrm{Sb}$ & $\begin{array}{l}\text { It serves for improving of corrosion resistance in salty water solutions; in } \mathrm{Al}-\mathrm{Mg} \text { compositions decreases } \\
\text { tendency to crack generation }\end{array}$ \\
\hline $\mathrm{Cr}$ & $\begin{array}{l}\text { Alloying with this element decreases susceptibility of grain growth in Al-Mg alloys; in hardenable alloys it } \\
\text { increases hardening capacity }\end{array}$ \\
\hline $\mathrm{Cu}$ & $\begin{array}{l}\text { It decreases solidification shrinkage and enables thermal hardening; undesirable effect is a decrease in corrosion } \\
\text { resistance; most often it is used along with } \mathrm{Mg}\end{array}$ \\
\hline Co & $\begin{array}{l}\text { In some Al-Si alloys with Fe present, it is added to transform needle-shape } \beta \text { phase rich in iron into sphere } \\
\text { morphology; this improves strength and plastic properties }\end{array}$ \\
\hline $\mathrm{Fe}$ & $\begin{array}{l}\text { In } \mathrm{Al}-\mathrm{Si} \text { alloys, it occurs as an impurity; solubility in solid state is low (approx. } 0.04 \% \text { ); due to this, it is present in } \\
\text { structure as intermetallic compound with aluminium } \mathrm{Al}_{5} \mathrm{FeSi} \text {; in } \mathrm{Al}-\mathrm{Cu} \text { alloys it creates intermetallic compound } \\
\mathrm{Al}_{7} \mathrm{FeCu}_{2} \text {, thus reducing copper content in solid solution } \alpha \text { which leads to a decrease of strength properties }\end{array}$ \\
\hline $\mathrm{Mg}$ & $\begin{array}{l}\text { It is alloyed in order to increase strength properties by hardening formation of intermetallic compound } \mathrm{Mg}_{2} \mathrm{Si} \\
\text { it deteriorates fluidity and improves machinability }\end{array}$ \\
\hline $\mathrm{Mn}$ & $\begin{array}{l}\text { It is alloyed into aluminium alloys in order to improve strength, to increase recrystallization temperature, to } \\
\text { refine grains, to block grain growth in the case of its segregation in form of disperse precipitates, and to suppress } \\
\text { iron segregation in lamellar form; for elimination of harmful iron influence, it is usually added in half content of } \\
\text { the iron content }\end{array}$ \\
\hline Mo & It is alloyed up to $0.3 \%$ in order to refine structure \\
\hline $\mathrm{Ni}$ & $\begin{array}{l}\text { It is alloyed in order to improve strength of } \mathrm{Al}-\mathrm{Cu}, \mathrm{Al}-\mathrm{Si} \text { alloys at higher temperatures; it improves corrosion } \\
\text { resistance }\end{array}$ \\
\hline $\mathrm{Si}$ & $\begin{array}{l}\text { In Al-Si alloys, it is the main alloying element, presence of which improves casting properties; comparing with } \\
\text { properties of pure aluminium, depending of silicium content, strength is increased }\end{array}$ \\
\hline $\mathrm{Ti}$ & It is alloyed together with $\mathrm{B}$ in order to refine structure \\
\hline
\end{tabular}

content higher than $1-1.4 \%$ has negative impact on the cast properties $[5,6,11]$.

\section{Materials and Methods}

2.1. Preparation of Experimental Casts. Casting machine CLH 400.01 was applied for the experimental casting. It is horizontal pressure machine with cold chamber, with manual dosing of metal. Other operations of casting process run in semiautomatic cycle, so that all conditions of casting cycle could be replicated. In semiautomatic regime of the machine with horizontal cold chamber, an operator manually scoops up metal with the scoop from the heating furnace and pours it into loading chamber. All other operations including ejection of the cast from the mould are automatic with electrohydraulic safety system for particular operations.

Set of 80 specimens were cast at a given technological order (Table 2). Every eighth cast specimen were selected for experimental evaluation, so that the whole range of usable capacity of the heating furnace would be represented.

2.2. Evaluation Method by Pressure Tests of Residual Deformation. This is a type of pressure test which follows residual deformation; the term residual deformation means deformation measured at partial unload discharge. The load is evoked by force $F_{E 1}$. When maximal value of deformation evoked by
TABLE 2: Technological order and casting parameters.

\begin{tabular}{lc}
\hline Basic pressure & $30 \pm 2 \mathrm{MPa}$ \\
Path of third velocity & $270 \mathrm{~mm}$ \\
Third velocity & $2.5 \mathrm{rev}$ \\
Chamber diameter & $60 \mathrm{~mm}$ \\
Size of pellet & $25 \mathrm{~mm}$ \\
Temperature of meltage & $660 \pm 20^{\circ} \mathrm{C}$ \\
Insert under the chamber & $40 \mathrm{~mm}$ \\
Dose mass into chamber & $1300 \mathrm{~g}$ \\
Dosing scoop number & 5 \\
Cycle time & $50.42 \mathrm{~s}$ \\
Solidification time & $4 \mathrm{~s}$ \\
Pressing time & $5 \mathrm{~s}$ \\
Unload discharge time & $2 \mathrm{~s}$ \\
\hline
\end{tabular}

this force is reached, the value of the force is decreased to value $F_{E 2}$. Time of force $F_{E 2}$ effect is usually $10 \mathrm{~s}$.

It holds true that

$$
F_{E 2}=\frac{1}{2} F_{E 1}
$$

Residual deformation tests were carried out on device TIRA test 28200. Initial load force was set on value $F_{E 1}=$ $86 \mathrm{kN}$ with loading speed $10 \mathrm{~mm} \mathrm{~s}^{-1}$. When maximum 
TABLE 3: Intervals of contents of particular elements as stated by the norm STN EN 424331.

\begin{tabular}{cccccccccccccc}
\hline & $\mathrm{Si}(\%)$ & $\mathrm{Fe}(\%)$ & $\mathrm{Cu}(\%)$ & $\mathrm{Mn}(\%)$ & $\mathrm{Mg}(\%)$ & $\mathrm{Zn}(\%)$ & $\mathrm{Ni}(\%)$ & $\mathrm{Cr}(\%)$ & $\mathrm{Pb}(\%)$ & $\mathrm{Sn}(\%)$ & $\mathrm{Ti}(\%)$ & $\mathrm{V}(\%)$ & $\mathrm{Al}(\%)$ \\
\hline Min. & 8.00 & 0.60 & 2.00 & - & 0.05 & - & - & - & - & - & - & - & - \\
Max. & 11.00 & 1.10 & 4.00 & 0.55 & 0.55 & 1.20 & 0.55 & 0.03 & 0.35 & 0.25 & 0.25 & - & - \\
\hline
\end{tabular}

TABLE 4: Values of chemical compositions of particular cast samples and values of residual deformation.

\begin{tabular}{lcccccccccccccc}
\hline Sample & $\mathrm{Si}(\%)$ & $\mathrm{Fe}(\%)$ & $\mathrm{Cu}(\%)$ & $\mathrm{Mn}(\%)$ & $\mathrm{Mg}(\%)$ & $\mathrm{Zn}(\%)$ & $\mathrm{Ni}(\%)$ & $\mathrm{Cr}(\%)$ & $\mathrm{Pb}(\%)$ & $\mathrm{Sn}(\%)$ & $\mathrm{Ti}(\%)$ & $\mathrm{V}(\%)$ & $\mathrm{Al}(\%)$ & $\mathrm{Def}(\mathrm{mm})$ \\
\hline $\mathrm{A} 1$ & 9.87 & 0.91 & 2.27 & 0.28 & 0.14 & 0.74 & 0.06 & 0.03 & 0.12 & 0.04 & 0.03 & 0.01 & 85.50 & 0.293 \\
$\mathrm{~B} 1$ & 9.88 & 0.89 & 2.31 & 0.27 & 0.13 & 0.76 & 0.06 & 0.03 & 0.12 & 0.04 & 0.03 & 0.01 & 85.48 & 0.290 \\
$\mathrm{~A} 2$ & 9.72 & 0.87 & 2.24 & 0.26 & 0.14 & 0.74 & 0.06 & 0.03 & 0.12 & 0.04 & 0.03 & 0.01 & 85.74 & 0.296 \\
$\mathrm{~B} 2$ & 9.76 & 0.88 & 2.22 & 0.27 & 0.13 & 0.74 & 0.06 & 0.03 & 0.12 & 0.04 & 0.03 & 0.01 & 85.71 & 0.292 \\
$\mathrm{~A} 3$ & 9.72 & 0.87 & 2.29 & 0.26 & 0.13 & 0.76 & 0.06 & 0.03 & 0.12 & 0.04 & 0.03 & 0.01 & 85.68 & 0.295 \\
$\mathrm{~B} 3$ & 9.51 & 0.86 & 2.2 & 0.27 & 0.12 & 0.74 & 0.06 & 0.03 & 0.11 & 0.04 & 0.03 & 0.01 & 85.99 & 0.291 \\
$\mathrm{~A} 4$ & 9.49 & 0.87 & 2.24 & 0.27 & 0.13 & 0.75 & 0.06 & 0.03 & 0.12 & 0.05 & 0.03 & 0.01 & 85.95 & 0.316 \\
$\mathrm{~B} 4$ & 9.39 & 0.85 & 2.21 & 0.25 & 0.13 & 0.73 & 0.06 & 0.03 & 0.12 & 0.04 & 0.03 & 0.01 & 86.14 & 0.313 \\
$\mathrm{~A} 5$ & 9.41 & 0.83 & 2.24 & 0.25 & 0.13 & 0.74 & 0.06 & 0.03 & 0.12 & 0.05 & 0.03 & 0.01 & 86.08 & 0.312 \\
$\mathrm{~B} 5$ & 9.48 & 0.85 & 2.24 & 0.25 & 0.13 & 0.74 & 0.06 & 0.03 & 0.12 & 0.05 & 0.03 & 0.01 & 86.00 & 0.311 \\
A6 & 9.3 & 0.82 & 2.19 & 0.25 & 0.14 & 0.76 & 0.06 & 0.03 & 0.12 & 0.05 & 0.03 & 0.01 & 86.20 & 0.327 \\
B6 & 9.47 & 0.85 & 2.21 & 0.25 & 0.14 & 0.76 & 0.06 & 0.03 & 0.12 & 0.05 & 0.03 & 0.01 & 86.02 & 0.305 \\
A7 & 9.49 & 0.85 & 2.22 & 0.24 & 0.13 & 0.75 & 0.06 & 0.03 & 0.12 & 0.04 & 0.03 & 0.01 & 86.03 & 0.316 \\
B7 & 9.41 & 0.83 & 2.16 & 0.25 & 0.13 & 0.75 & 0.06 & 0.03 & 0.11 & 0.04 & 0.03 & 0.01 & 86.19 & 0.306 \\
A8 & 9.32 & 0.81 & 2.25 & 0.22 & 0.13 & 0.75 & 0.06 & 0.02 & 0.12 & 0.05 & 0.03 & 0.01 & 86.23 & 0.334 \\
B8 & 9.28 & 0.83 & 2.24 & 0.23 & 0.13 & 0.75 & 0.06 & 0.02 & 0.12 & 0.05 & 0.03 & 0.01 & 86.25 & 0.338 \\
A9 & 9.34 & 0.81 & 2.28 & 0.22 & 0.13 & 0.75 & 0.06 & 0.02 & 0.12 & 0.05 & 0.02 & 0.01 & 86.19 & 0.331 \\
B9 & 9.23 & 0.79 & 2.21 & 0.23 & 0.13 & 0.76 & 0.06 & 0.02 & 0.12 & 0.05 & 0.03 & 0.01 & 86.36 & 0.336 \\
A10 & 9.44 & 0.81 & 2.25 & 0.23 & 0.13 & 0.75 & 0.06 & 0.03 & 0.12 & 0.05 & 0.03 & 0.01 & 86.09 & 0.33 \\
B10 & 9.32 & 0.8 & 2.24 & 0.22 & 0.13 & 0.73 & 0.06 & 0.03 & 0.12 & 0.04 & 0.04 & 0.01 & 86.26 & 0.323 \\
\hline
\end{tabular}

deformation value was reached, the load was decreased to the value $F_{E 2}=43 \mathrm{kN}$, at which the residual deformation was observed during $10 \mathrm{~s}$. Measurements were carried out on ten specimens, courses were recorded and processed by system TIRA test. Ambient temperature during tests was kept at $23 \pm 0.5^{\circ} \mathrm{C}$.

2.3. Observing Chemical Composition of the Casts. Analysis of chemical composition was observed on spectrophotometer SPECTROLAB JR.CCD 2000. Measurements provided chemical compositions of the casts in the place of openings (A, B). The samples were detached in such a way that no thermal impacts have occurred. Surfaces were adjusted by milling technology. Shape of the samples was formed to achieve square plane with a side of $20 \mathrm{~mm}$. Three measurements for every sample were carried out according to procedure for chemical composition measurements by spark erosion.

The analysis of the casts provides mass content percentage of the following elements: $\mathrm{Si}, \mathrm{Fe}, \mathrm{Cu}, \mathrm{Mn}, \mathrm{Mg}, \mathrm{Zn}, \mathrm{Ni}, \mathrm{Cr}, \mathrm{Pb}$, $\mathrm{Sn}, \mathrm{Ti}, \mathrm{Na}, \mathrm{Sr}, \mathrm{V}, \mathrm{Zr}$, and Al. Table 3 shows values of boundary intervals of contents for particular elements according to the norm STN EN 424331.

\section{Results}

3.1. Chemical Composition. The results of chemical composition measurements have shown decrease in the content of observed elements in casting process. Particular casts indicate variations of the contents with decreasing tendency. The results directly correspond to the results of observation of content changes in heating furnace that are described in contributions dealing with casting process variations $[21,22]$. The results are given in Table 4.

From measurements of the chemical composition of each sample (Table 4), the track of changes to the content of the particular elements, depending on the time, can be kept. These changes are directly reflected in the element content of castings, and interval of the change is $7.04 \%$ for $\mathrm{Si}, 15.19 \%$ for $\mathrm{Fe}$, and $27.27 \%$ for $\mathrm{Mn}$.

On the basis of the analysis, it was suggested to stabilize or slightly increase iron content and to directly increase manganese content. An iron content should be up to one percent because-as it is given in the theory and also prescribed by the norm-exceeding of iron content above $1.4 \%$ causes strong negative effects $[6,11]$. Relation of iron and manganese content was determined on the basis of measurements to $3.15: 1$. According to this relation and to 
TABLE 5: Obtained content values of chosen elements ( $\mathrm{Si} / \mathrm{Fe} / \mathrm{Mn}$ ) of particular samples of the casts and values of residual deformation after content correction of Fe-Mn.

\begin{tabular}{lcccc}
\hline Sample & Si $(\%)$ & Fe $(\%)$ & Mn $(\%)$ & Def. $(\mathrm{mm})$ \\
\hline A11 & 9.5 & 0.95 & 0.35 & 0.284 \\
B11 & 9.58 & 0.98 & 0.35 & 0.282 \\
A12 & 9.26 & 0.94 & 0.35 & 0.287 \\
B12 & 9.46 & 0.96 & 0.34 & 0.284 \\
A13 & 9.22 & 0.91 & 0.3 & 0.29 \\
B13 & 9.34 & 0.94 & 0.34 & 0.29 \\
A14 & 9.18 & 0.94 & 0.32 & 0.293 \\
B14 & 9.3 & 0.93 & 0.32 & 0.293 \\
A15 & 9.07 & 0.91 & 0.31 & 0.294 \\
B15 & 9.24 & 0.91 & 0.31 & 0.296 \\
A16 & 9.06 & 0.87 & 0.3 & 0.296 \\
B16 & 9.17 & 0.86 & 0.3 & 0.298 \\
\hline
\end{tabular}

cast manufacturer requirements, also taking into account possibilities to change alloy composition, the iron content for further experimental evaluation was set on value 0.90 to $0.95 \% \mathrm{Fe}$, and the manganese content was set $0.35 \%$ to $0.38 \%$ Mn.

The experiment that followed was based on suggested iron and manganese content values. The set of casts was produced with the same methodology as in previous case. Six casts from the set were selected for residual deformation and chemical composition analyses. Obtained values are shown in Table 5.

Dependence courses of particular casts on chemical composition on casting order of the casts are given in Figure 1.

3.2. Residual Deformation. In this part, dependence courses of residual deformation on chemical composition of the casts are observed. Particular influences of chosen alloying elements are given in introductory part of the paper. An influence of iron and manganese on resulting residual deformation was observed, at the same time, a possible influence of silicium content variation was evaluated. Considering that $\mathrm{Si}$ influences fluidity, all observed casts were X-ray tested, and no internal defects were detected. Also, visual and dimensional inspections did not show any negative changes of the casts. Figure 2 gives dependence courses of residual deformation on chosen elements content.

\section{Discussion}

4.1. Influence of Iron and Manganese Contents on Values of Residual Deformation. For increasing values of iron content, it is possible to see the decrease of residual deformation values (Figure 2, Fe (wt.), exp. I). The decrease is also observed at the manganese content increase (Figure 2, Mn (wt.), exp. I). In proposal for iron content in aluminium alloy, the content intervals were suggested, and these intervals were not exceeded during analyses. In one case, the iron content value $(0.98 \%)$ exceeded recommended range $(0.90$ to $0.95 \% \mathrm{Fe})$; however, no negative effect was observed.

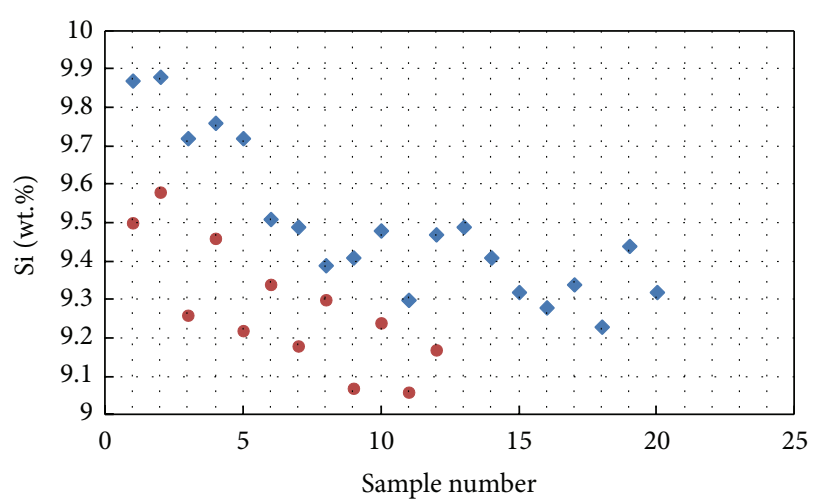

(a)

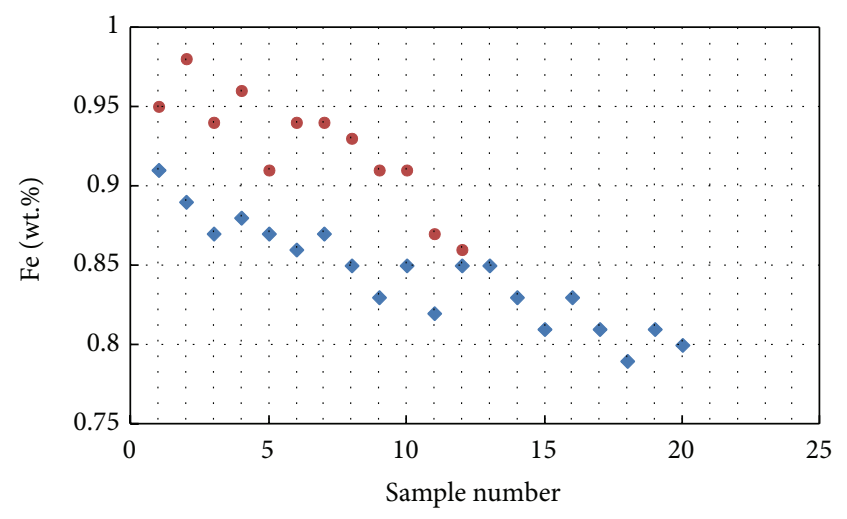

(b)

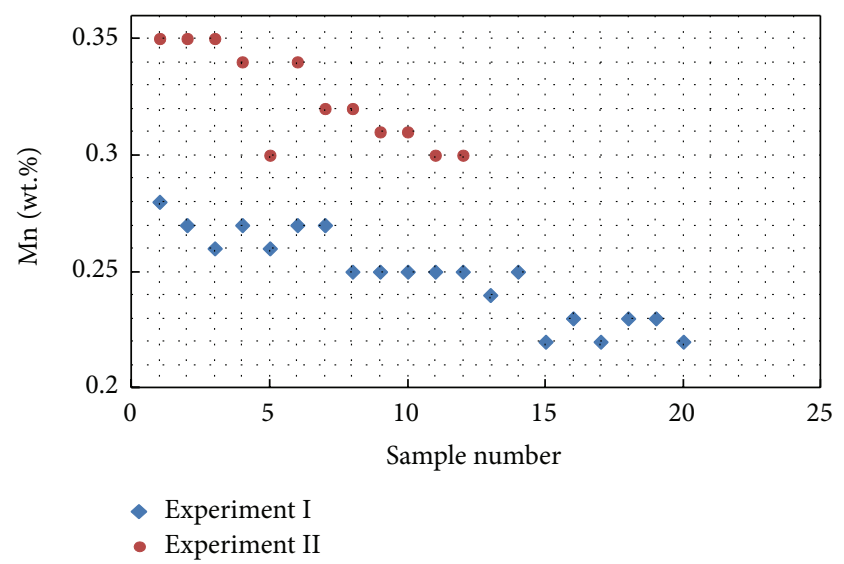

(c)

FIGURE 1: Values of chemical composition ( $\mathrm{Si} / \mathrm{Fe} / \mathrm{Mn})$ for the experiments.

Figure 2 shows diagrams representing whole range of observed iron and manganese contents and residual deformations which depend on those contents. From the diagrams, the decrease in residual deformations in dependence on alloying elements increase is apparent. The recorded decrease for residual deformation was $19.85 \%$ for the observed samples. The coupling of the iron content and manganese content can be observed also; this is represented by residual deformation. The test of functional dependences was carried out. At first, the correlations between iron and manganese contents 


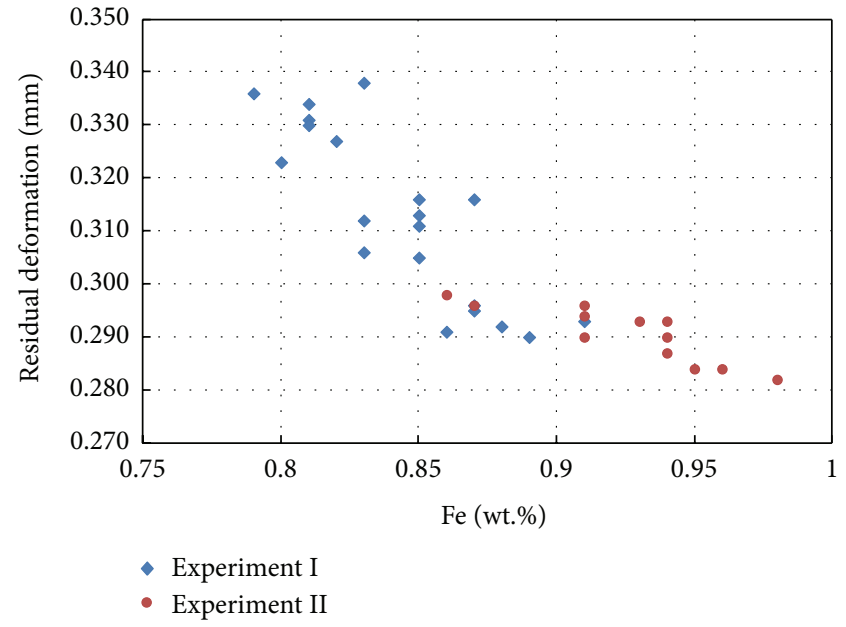

(a)

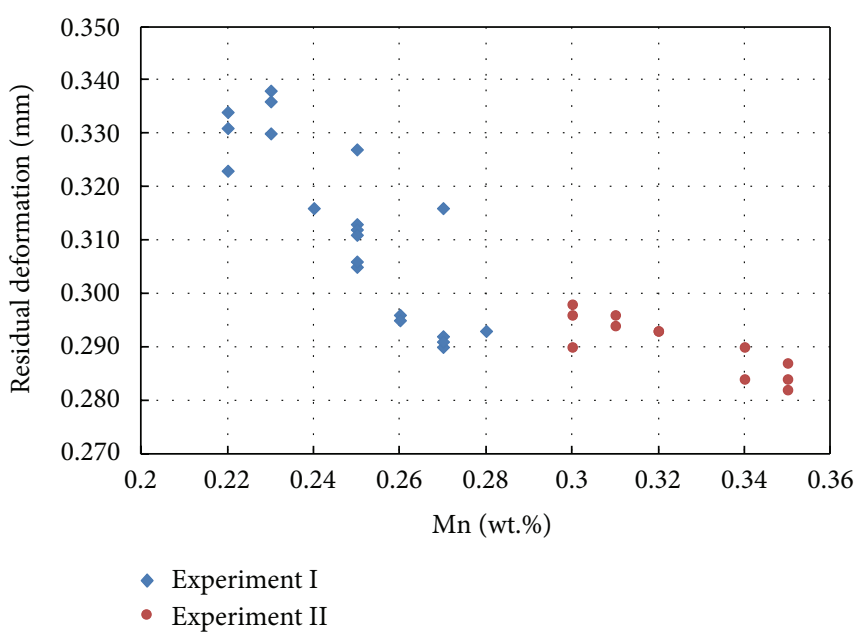

(b)

FIgURE 2: Dependence courses of residual deformation on change of Fe and Mn content.

in aluminium alloy and residual deformation were observed independently. In the following, the complex dependences between the parameters were described. For analyzed places $\mathrm{A}$ and $\mathrm{B}$, the value of correlation coefficient for measuring of iron content and residual deformation was determined on -0.868 , and for manganese content and residual deformation, it was determined on -0.838 . The mutual correlation between iron and manganese content was determined on 0.944 . Values of correlation coefficients indicate indirect functional dependences between iron content, manganese content, and residual deformation. Values approach significantly the value -1 , so the high degree of the correlation can be noted. Multiple coefficient of correlation for analyses in places $A$ and $B$ has value 0.0954. Cummulative characteristic of residual deformation dependence on $\mathrm{Mn}$ and $\mathrm{Fe}$ content is shown in Figure 3. Differences between measured-out points and theoretical area fall within supposed range, whilst mutual relations of $\mathrm{Mn}$ and Fe changes can be observed. The behaviour can be explained from metallurgy point of view by formation of structures on the $\mathrm{Al}-\mathrm{Fe}-\mathrm{Mn}-\mathrm{Si}$ basis and their variations, with an assumption that structures with lesser content of alloying elements contain more massive formations of intermetallic phases $\mathrm{Al}(\mathrm{FeMn}) \mathrm{Si}$ and lower content of Mn causes more frequent occurrence of intermetallic ferritic phase $\mathrm{Al}_{3} \mathrm{FeSi}$ [11]. This was the reason to carry out analysis to evaluate the samples. Therefore, the metallographic analysis was carried out to evaluate the particular samples in terms of the formation of structures as well as their possible effect on the mechanical properties of the casts.

From the analysis of microscopic images, it follows that structures of A1, A2, B1, and B2 samples (Figure 4) contain fine structural zones of intermetallic phases $\mathrm{Al}(\mathrm{FeMn}) \mathrm{Si}$ and defects in the form of bubbles in dimensional range $\langle 8 ; 11\rangle \mu \mathrm{m}$. Structures of A8, A9, B8, and B9 (Figure 4), on the other side, contain more massive structural zones of intermetallic phases $\mathrm{Al}(\mathrm{FeMn}) \mathrm{Si}$ and internal defects in greater dimensional interval $\langle 10 ; 30\rangle \mu \mathrm{m}$. Also the structures

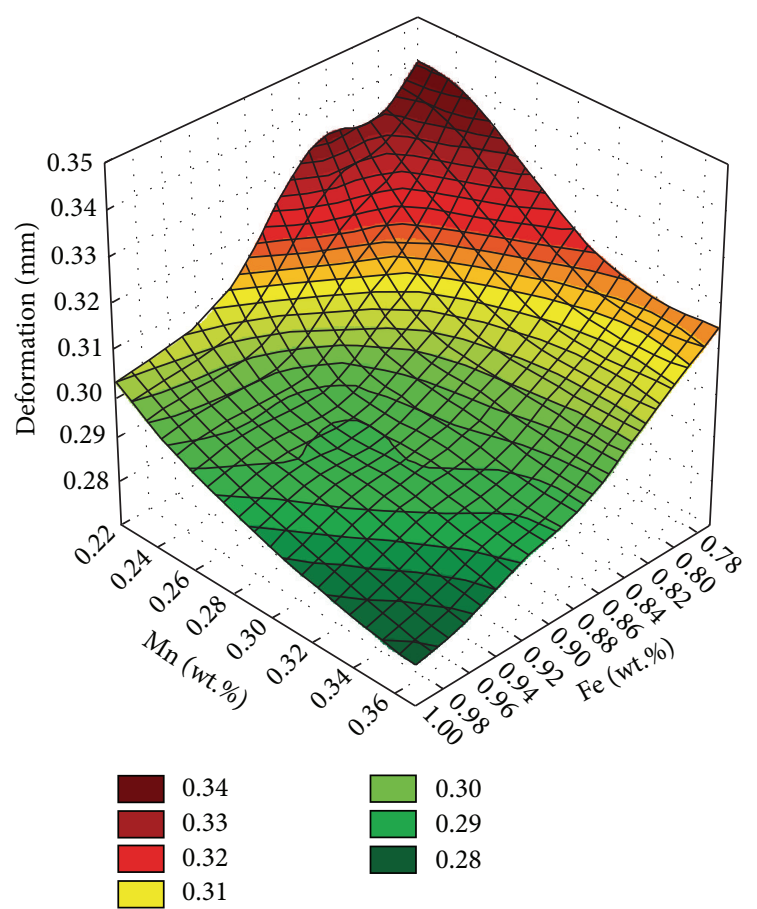

FIGURE 3: Dependence of permanent deformation on iron and manganese.

of ferritic phase $\mathrm{Al}_{3} \mathrm{FeSi}$ and intermetallic phase $\mathrm{FeSiAl}_{5}$ are observed as more massive needles. In the case of $\mathrm{FeSiAl}_{5}$, long needles are forming; these can cause defects due to the notch effect. Variations of ferritic phase $\mathrm{Al}_{3} \mathrm{FeSi}$ from massive and more frequent in samples A8, A9, B8, and B9 to finer and less frequent in samples $\mathrm{A} 1, \mathrm{~A} 2, \mathrm{~B} 1$, and $\mathrm{B} 2$ correspond to the increase in Mn content. All images also show particles of undissolved silicium in a form of irregular objects.

More massive structural zones of ferritic phase $\mathrm{Al}_{3} \mathrm{FeSi}$ have negative effects on values of residual deformation, 
(A1)

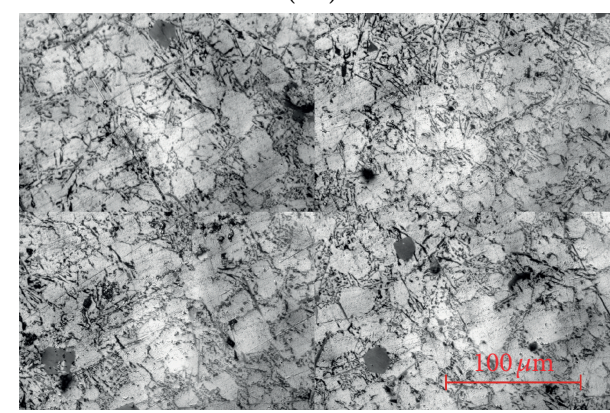

(A2)

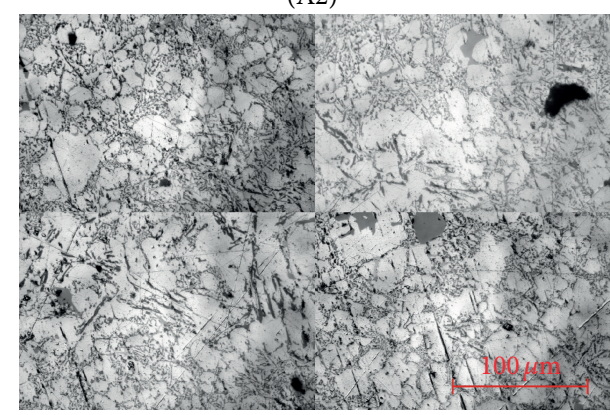

(A8)

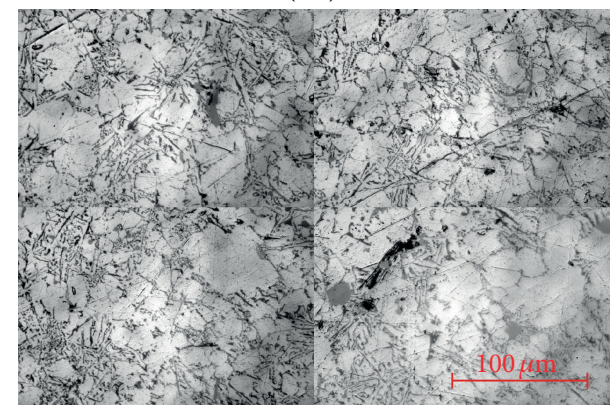

(A9)

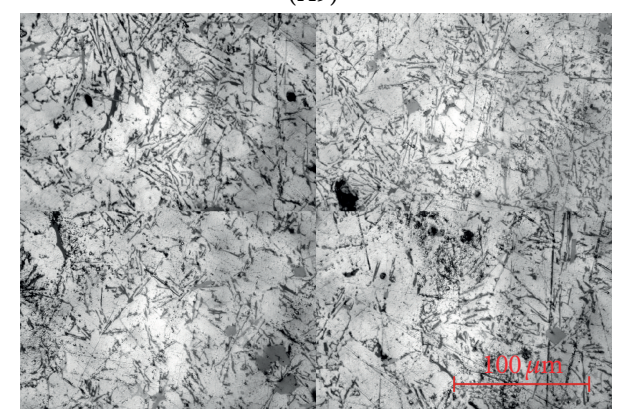

(B1)

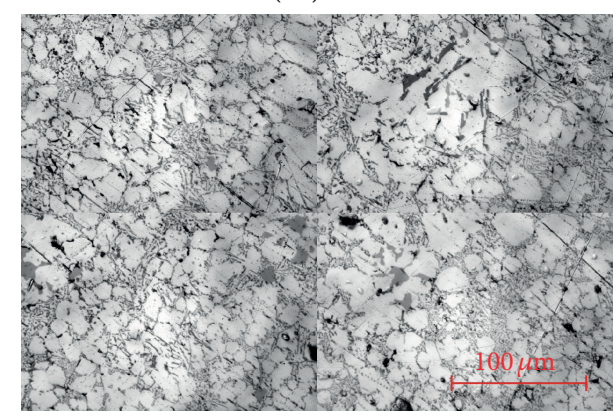

(B2)

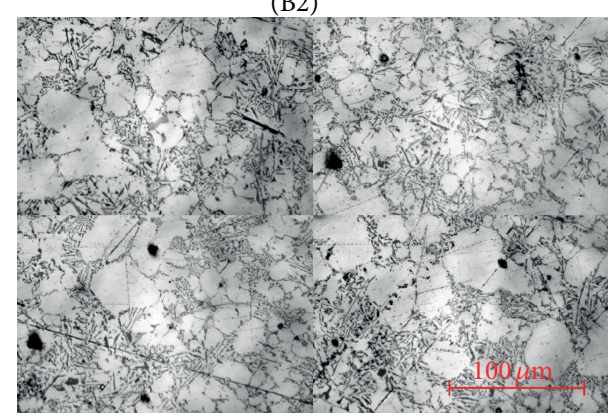

(B8)

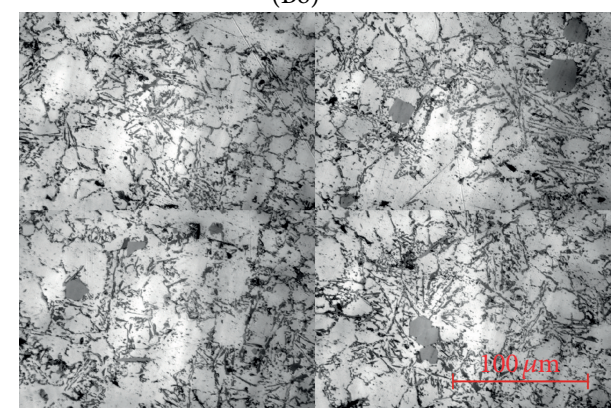

(B9)

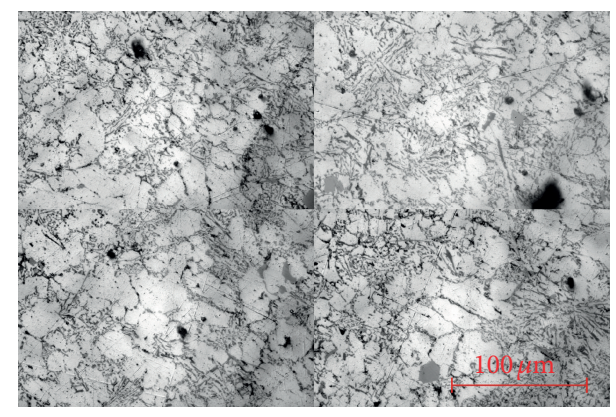

FIGURE 4: Metallographic images of boundary casts.

while they are compensated by increasing manganese content which causes refining of $\mathrm{Al}_{3} \mathrm{FeSi}$ phase and formation of intermetallic $\mathrm{Al}(\mathrm{FeMn}) \mathrm{Si}$ phases. These structures are more beneficial in terms of exposure to residual deformation.

In the case of manganese, it is necessary to observe the correlation, because if it is not saturated, and it is eventually deposited as a thermal compound AlMnSi.

\section{Conclusions}

Realized experiments and discussions show several important aspects of obtained and verified knowledge. Experiments were focused on a group of three elements ( $\mathrm{Si}, \mathrm{Fe}$, and $\mathrm{Mn}$ ) occurring in subeutectic Al-Si alloy. Selection of the group was based on knowledge of realized measurements obtained 
within monitoring of processes in heating furnaces, where variations of elements concentration have been observed. The variations relate to silicium, iron, and manganese, all in decreasing trends.

Described results also show that in casting process, concentration variation of silicium, iron, and manganese may occur, whilst these variations in the conditions of real experiment have reached values for Fe 15\%, for Mn 27\%, and for Si 7\%. Also, an influence of these variations on values of residual deformation was confirmed; theoretical approach was proved. The change of deformation in such a case is $16 \%$ from observed interval. At the same time, it is possible to evaluate correlation coupling of $\mathrm{Si} / \mathrm{Fe} / \mathrm{Mn}$ with regard to the metallographic tests results.

From verification measurements and from overall behaviour of particular ingredients, it can be concluded that even though the iron is an impurity, it can be used to increase compression strength for loads in incomplete unload discharge. The mean deformation value of standard meltage presents value $0.313 \mathrm{~mm}$ with standard deviation 0.0163 and variance of residual deformation $2.69 E-4$. Repeated tests with increased values of Fe and Mn contents showed decrease in mean deformation value to $0.2905 \mathrm{~mm}$ with standard deviation 0.0053 and variance of residual deformation $2.826 E-5$. Results demonstrated decrease in deformation on an average $7.6 \%$. In such a case, it is suitable to apply interval of $\mathrm{Fe}$ content up to $0.95 \%$ of mass content. However, it is vital to proportionally increase amount of manganese too, in order to refine structures. If the growth of needle-shape structures is significant, there is a chance of local defects in form of slipping planes; that is, why refined structures are sought for.

Taking into account the variations of alloy content comparing to commercial alloys, it is possible to ensure alloying elements content increase during melting process by subsidizing the particular ingredients or by proper combination of recurrent material.

\section{References}

[1] M. Sadeghi and J. Mahmoudi, "Experimental and theoretical studies on the effect of die temperature on the quality of the products in high-pressure die-casting process," Advances in Materials Science and Engineering, vol. 2012, Article ID 434605, 9 pages, 2012.

[2] E. Ragan, Väzkost' a Počiatočné Napätie v Intervale Kryštalizacie, FVT TU Košice so sidlom v Prešov, Prešov, Slovakia, 1997.

[3] E. Ragan and M. Fedak:, "Kvalita odliatku v závislosti na procese tlakového liatia," in Proceedings of Technology Systems Operation Conference (TSO '07), p. 2, FVT TU, Presov, Slovakia, 2007.

[4] J. Malik, P. Futáš, I. Vasková et al., "Nehomogenita tlakového odliatku z podeutektického silumynu," Slévárenství, vol. 55, no. 7, pp. 307-310, 2007.

[5] E. Ragan, Proces Liatia Pod Tlakom, FVT TU Košice so sídlom v Prešove, Prešov, Slovakia, 1997.

[6] E. Ragan and S. Fabian, Liatie Kovov Pod Tlakom, VMV, Prešov, Slovakia, 2007.

[7] P. Dzugas, J. Vilcko, D. Sulik, and J. Mester, "Experimentálne štúdium tuhnutia odliatkov zo zliatin typu Al-Si liatych s tuhnutím pod tlakom-part III," Slévárenství, no. 1, pp. 7-8, 1992.
[8] E. J. Vinarcik, High Integrity Die Casting Processes, John Wiley and Sons, New York, NY, USA, 2003.

[9] E. Ragan, M. Fedak, and P. Skok, “Zabiehavost' v dutine formy pri technológií liatia pod tlakom," in Operation and Diagnostics of Machines and Production Systems Operational States: Scientific Papers, pp. 146-153, Tribun EU, Kraków, Poland, 2008.

[10] J. Laudar, Liatie Pod Tlakom, SVTL, Bratislava, Slovakia, 1964.

[11] D. Bolibruchová and E. Tillova, Zlievarenské Zliatiny Al-Si, Žilinská univerzita v Žiline, Žiline, Slovakia, 2005.

[12] T. Grígerová, R. Koreny, and I. Lukac, Zlievárenstvo neželezných kovov, ALFA, Bratislava, Slovakia, 1988.

[13] J. Jurko, M. Džupon, A. Panda, and J. Zajac, "Study influence of plastic deformation a new extra low carbon stainless steels XCr17Ni7MoTiN under the surface finish when drilling," Advanced Materials Research, vol. 538-541, pp. 1312-1315, 2012.

[14] J. ] Vilcko and S. Slovak, Zlievarenská Technológia, ALFA, Bratislava, Slovakia, 1987.

[15] V. Zabavnik and M. Bursak, Materiál, Tepelné Spracovanie, Kontrola Kvality, Hutnícka Fakulta-TUKE, Košiciach, Slovakia, 2004.

[16] I. Lukac, Vlastnosti a Štruktúra Neželezných Kovov, ALFA, Bratislava, Slovakia, 1987.

[17] J. Valecky, L. Jeníček, V. Oliverius et al., Lití Kovů pod Tlakem, SNTL, Praha, Czech Republic, 1963.

[18] J. Vilcko and P. Dzugas, "Liatie s tuhnutím pod tlakom zo zliatin typu Al-Si, Úvod do problematiky technológie výroby vysokokvalitných odliatkov (čast' I)," Slévárenství, no. 12, pp. 499-504, 1990.

[19] A. Gorny, J. Manickaraj, Z. Cai, and S. Shankar, "Evolution of Fe based intermetallic phases in $\mathrm{Al}-\mathrm{Si}$ hypoeutectic casting alloys: influence of the $\mathrm{Si}$ and $\mathrm{Fe}$ concentrations, and solidification rate," Journal of Alloys and Compounds, vol. 577, pp. 103-124, 2013.

[20] S. Ji, W. Yang, F. Gao, D. Watson, and Z. Fan, "Effect of iron on the microstructure and mechanical property of Al-Mg-Si-Mn and Al-Mg-Si diecast alloys," Materials Science and Engineering A, vol. 564, pp. 130-139, 2013.

[21] M. Fedak, P. Semanco, and M. Micko, "Statistical process control method based on weight percent of Al-Si alloy for melting and holding process in die casting," in Lecture Notes of the Institute for Computer Sciences, Social Informatics and Telecommunications Engineering, vol. 62, pp. 188-190, 2012.

[22] M. Fedak and P. Semanco, "Monitoring of chemical composition of aluminium alloys Al-Si in the maintenance furnace," in Scientific Papers: Operation and Diagnostics of Machines and Production Systems Operational States, vol. 3, pp. 139-144, RAM, Lüdenscheid, Germany, 2010. 

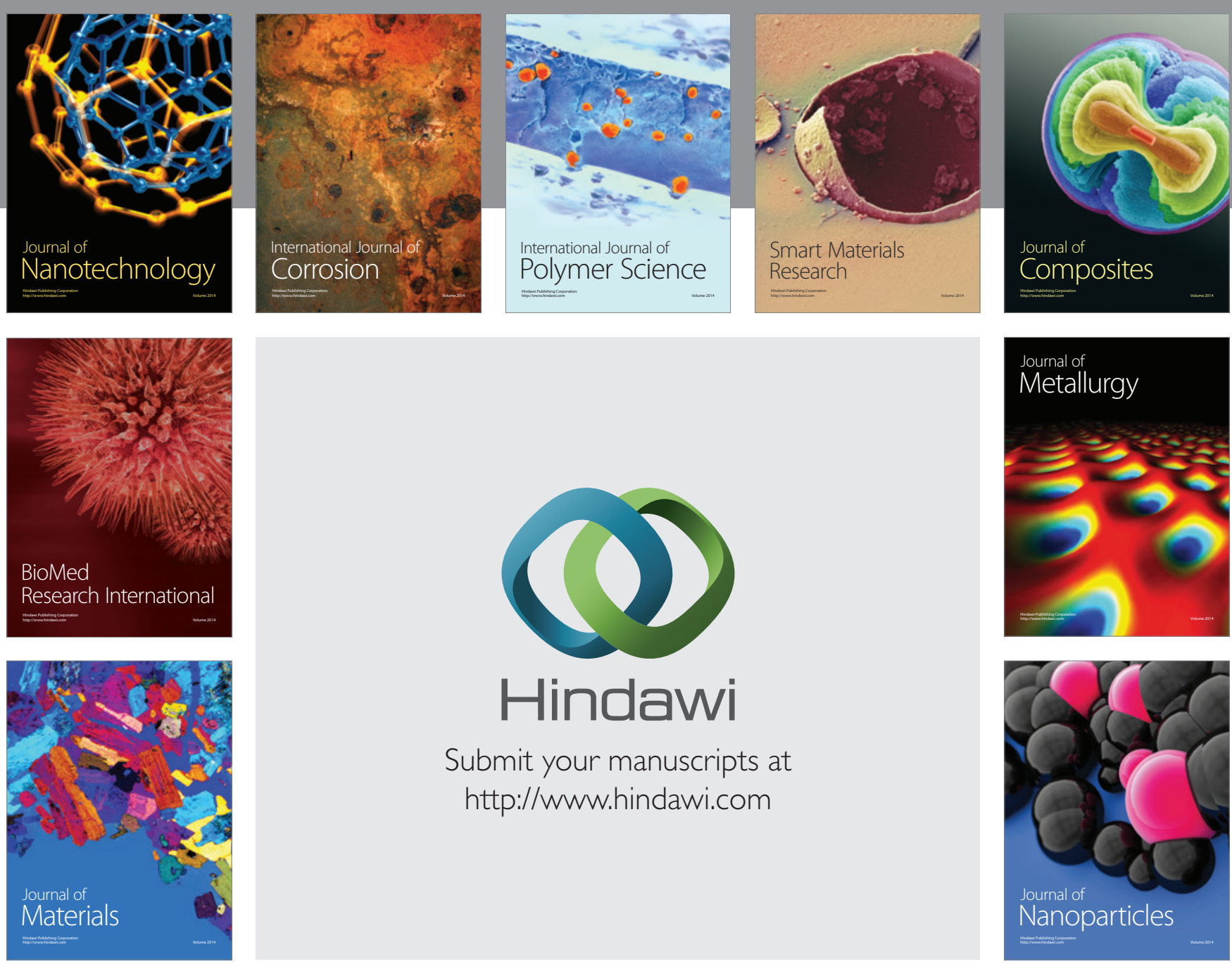

Submit your manuscripts at http://www.hindawi.com
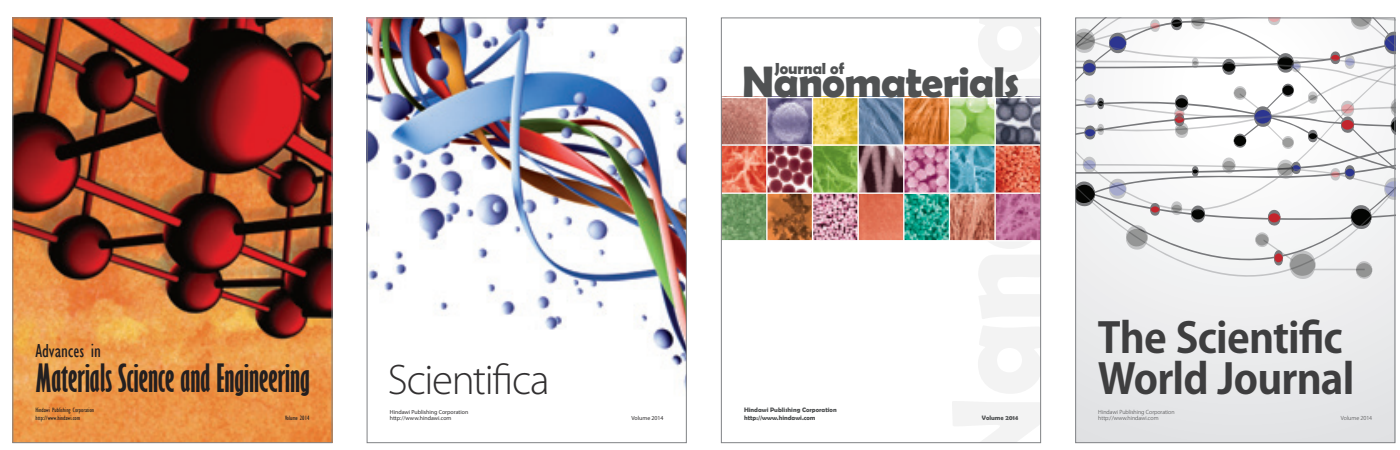

\section{The Scientific World Journal}
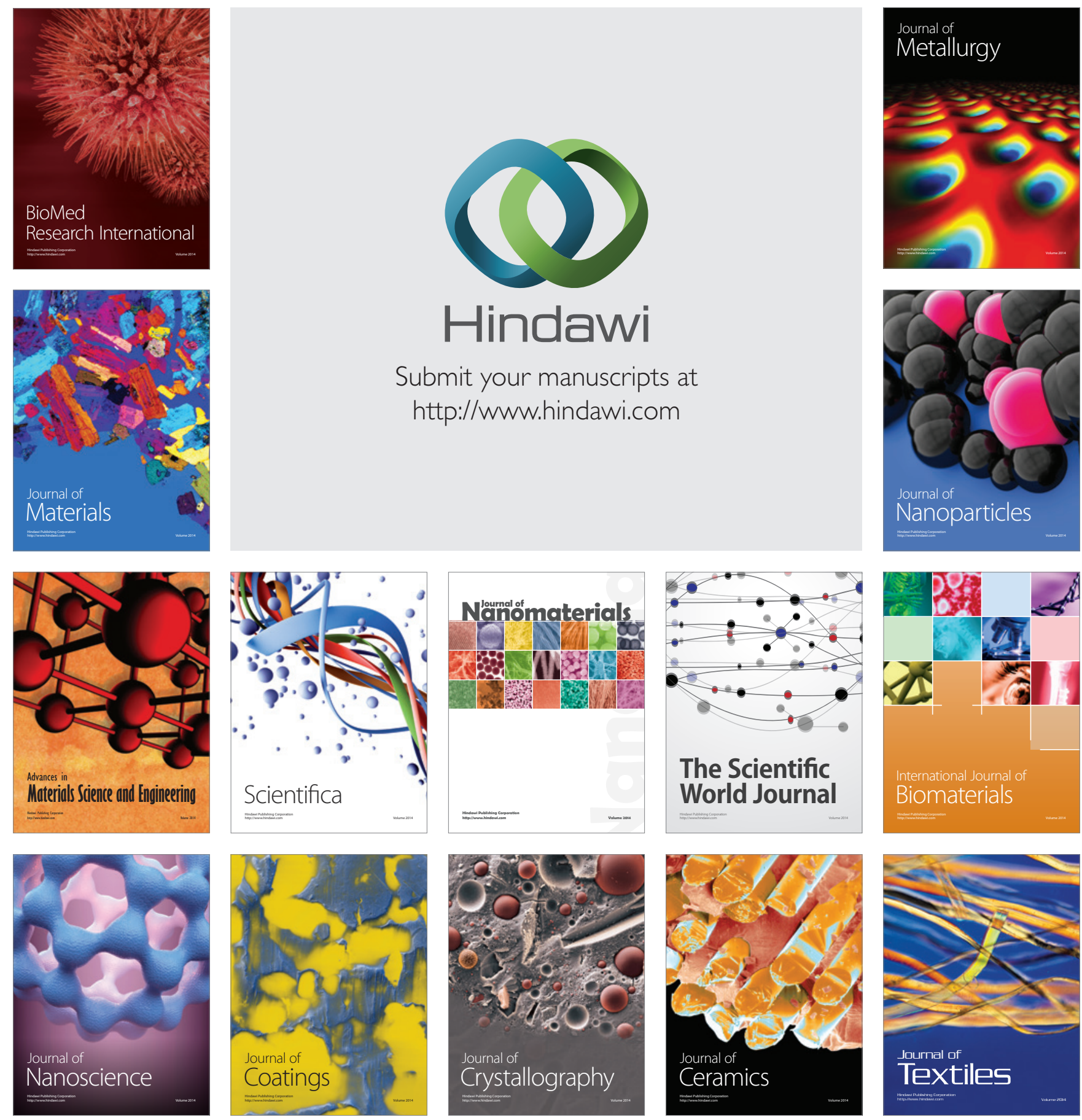